\title{
ANCIENT BATHING PLACES OF CENTRAL JAVA A SHORT SURVEY
}

Due to their fine sculpture and lush setting, the bathing places of East Java and Bali have long attracted the interest of scholars and travellers alike. Today, Belahan, Jolotundo and Goa Gajah count among the most famous archaeological sites of the Indonesian archipelago. In this paper, I want to bring to mind the existence of similar vestiges in Central Java. I would also like to underline that, since decorated bathing places are unknown in India but constitute a common building type in East Javanese architecture, ${ }^{1}$ their existence in Central Java shows the continuity existing between the arts of Central and East Java, the divergences between which have so often been overemphasized. In the following pages I propose to survey and describe briefly the bathing places of Central Java, both extant and lost, to analyse their similarities and differences, and to advance hypotheses about their significance and function.

\section{Survey of the bathing places of Central Java}

In Central Java, six sites have yielded in situ remains of bathing places: Cabean Kunti, Payak, Ratu Boko, Umbul, Kuwaringan, Pengilon and Sidomukti (fig. 1). Cabean Kunti, ${ }^{2}$ located near Boyolali, is certainly the most impressive bathing place of Central Java. The site is composed of five pools spread along the banks of the Kunti River, a small mountain stream flowing down Mount Merapi. The pools, which are still in use today, share roughly the same layout and dimensions: a rectangular basin measuring $4.70 \mathrm{~m}$. by $1.50 \mathrm{~m}$., bordered on three sides by a wall. Most of the baths were left uncarved, with the exception of the second pool to the west (Sendang Kunti) (fig. 2). On the inner side of the wall, one can see a now empty niche and panels carved with groups of birds alternating with human figures. A lingga, probably a boundary stone, is visible near the eastern bath.

A pool quite similar to Sendang Kunti - without ornamentation, however has been discovered in the village of Payak, ${ }^{3}$ along the Petir River, some ten kilometres south of Prambanan. This ancient bathing place consists of a single pool $(3.10 \mathrm{~m} . \times 3.20 \mathrm{~m}$.) bordered on three sides by a $1.70 \mathrm{~m}$. high wall, in the centre of which a small niche is visible. A ritual deposit box (peripih), now kept at the Prambanan museum, was found during restoration works.

We shall only mention very briefly the bathing complex of Ratu Boko, ${ }^{4}$ since it is in size, conception and location strikingly different from the other bathing places of Central Java. This bathing complex forms a small part of a larger site, the ruins of which are scattered on a dry, rocky hill overlooking Prambanan. The place was the seat of a large Buddhist monastery ( $8^{\text {th }}$ century AD), later on re-appropriated by Hindus. The actual bathing place is composed of at least 14 pools of various shapes and dimensions, all $\prod_{i a}$ free access 

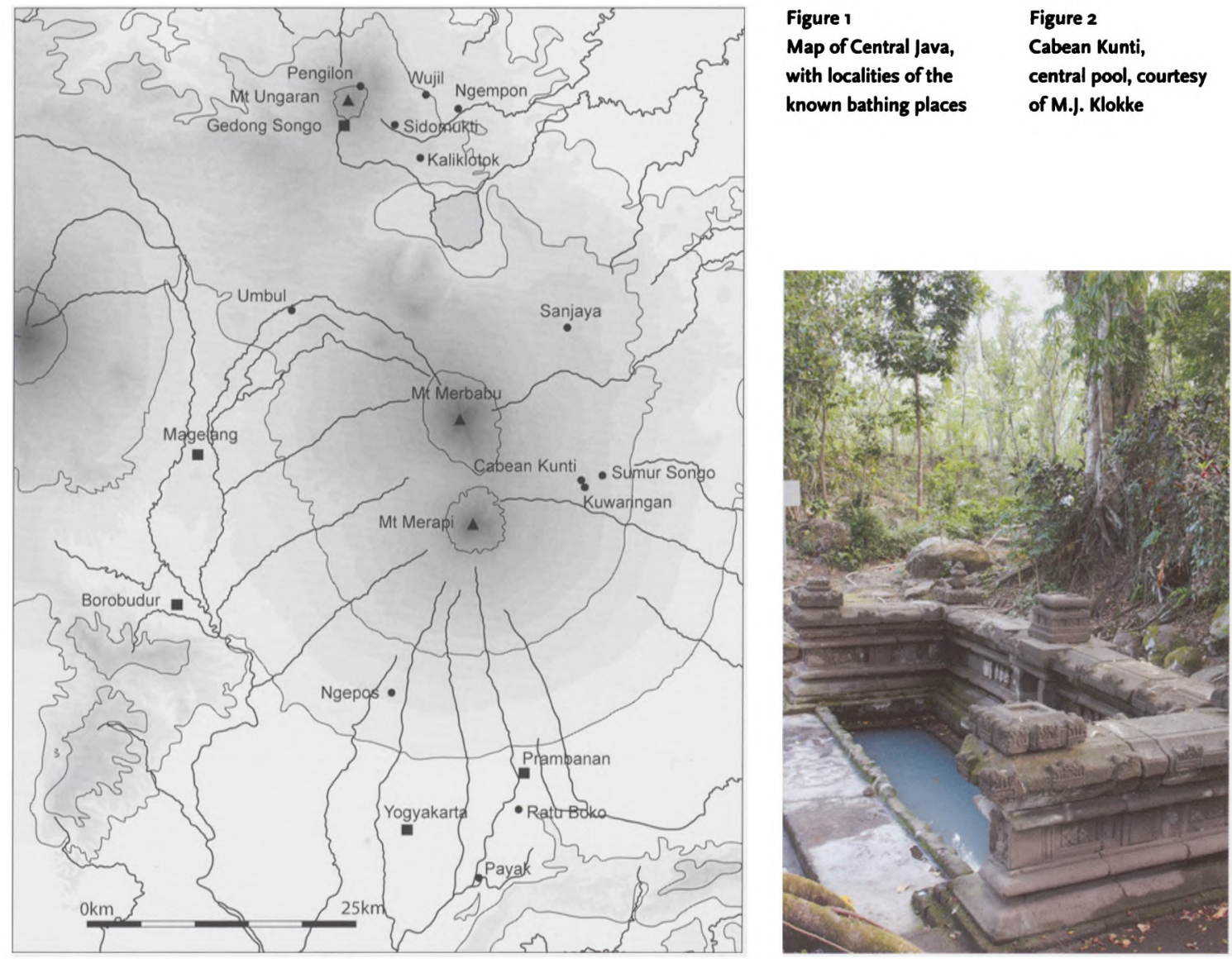

excavated out of the natural rock. Beside the bathing complex itself, several other pools and water tanks have been discovered at Ratu Boko.

The last well-preserved bathing place of Central Java, candi Umbul, 5 is located along the banks of the Elo River, in a lush green valley. The site consists of two pools built on hot springs (fig. 3). The upper pool measures $7.15 \mathrm{~m}$. (E-W) by $12.50 \mathrm{~m}$. (N-S). A staircase, located in its eastern side, descends into the pool, the floor of which is made of natural river stones. The second pool is slightly lower and is $8.5 \mathrm{~m}$. by $7 \mathrm{~m}$. It is linked to the upper pool by a $2 \mathrm{~m}$. long water duct, which allows water to flow from the upper to the lower basin. Among the numerous stones scattered around the pools, one can recognize several lingga, one yoni, one miniature temple and fragments of sculptures with bird-like lower limbs (possibly kinnari or garuda). Several other sculptures were discovered earlier in the vicinity, among others two Ganesha, two Durga and one Agastya. ${ }^{6}$ According to N.J. Krom, a garuda with a human body was also found among the ruins. ${ }^{7}$ The bathing places of Kuwaringan, Pengilon and Sidomukti are unfortunately no longer visible, but short descriptions of these places can be found in the literature. According to earlier reports, the site of Kuwaringan ${ }^{8}$ was actually a $6 \mathrm{~m}$. square water tank collecting the water from a spring called Candiraga. The tank was divided into two parts by a wall adorned with mouldings and pilasters. The part used as a bath was further divided into three by small walls. ${ }^{9}$ 


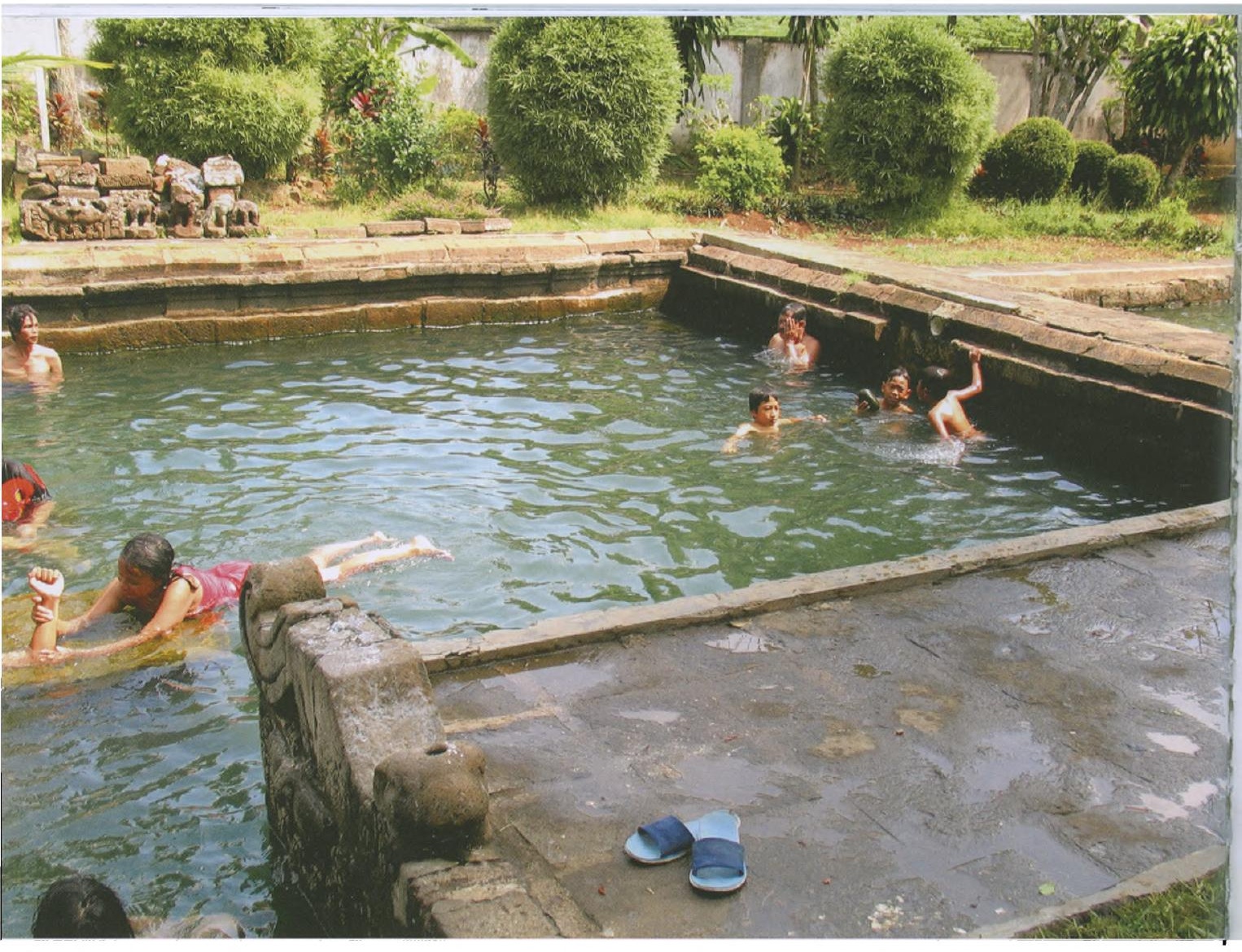

Figure 3

Candi Umbul, main pool, courtesy of H.I.R. Hinzler
At Candi Pengilon, on the slope of Mount Ungaran, were once visible the remains of a temple and a bathing place, linked by a stone staircase. A stone basin was built around a spring and a naga spout let the water flow from that tank to another basin. ${ }^{10}$ Several Ganesha, a lion and an elephant were discovered around the temple. ${ }^{11}$

Exploring the region around Mt Ungaran at the end of the $19^{\text {th }}$ century, R.H.T. Friederich noticed the presence, at Sidomukti, of a bathing place associated with a temple on a hilltop. ${ }^{12}$ The bathing complex was later described by N.J. Krom. It was composed of two pools, the water flowing from the smaller one into the larger one. ${ }^{13}$ In the vicinity were discovered two Ganesha and one Agastya, as well as two stone rams. ${ }^{14}$

Five other sites have been identified by archaeologists as possible bathing places: Bendosari, ${ }^{15}$ Kaliklotok, ${ }^{16}$ Ngepos, ${ }^{17}$ Sanjaya ${ }^{18}$ and Wujil. ${ }^{19}$ However, their state of preservation is very poor and they have not yielded any in situ remains of water tanks. Their identification as bathing places is thus a far from established fact, and mainly resides in the proximity of temple stones to a spring (Bendosari, Kaliklotok, Wujil and Sanjaya) or a river (Ngepos). ${ }^{20}$ Finally, I would like to add to this survey one site which is not a bathing place sensu stricto, but which is undoubtedly linked to water symbolism: Sumur Songo. ${ }^{21}$ In the $19^{\text {th }}$ century, remains of three temples were still visible on a hill overlooking the small Jurang River, but today only a series of eight wells remains, along the river banks. ${ }^{22}$ The lower part of these pits is partly 
excavated from the natural rock, partly built. In their upper part, almost all the pits show a few reused blocks (mouldings, antefixes). The fourth pit, however, seem to be pretty much in its original state. Its outer edge is profiled as a temple base or a yoni. Several sculptures were reported near the temple, among them an Agastya. ${ }^{23}$ In one of the pits was a relief showing men and women making offerings. ${ }^{24}$

\section{Characteristics, symbolism and function of a building type}

With the exception of Ratu Boko, all bathing places of Central Java share similar characteristics regarding their location and technology. They are located outside the main zones of settlement of the Hindu-Buddhist period, they are not found in association with large temple complexes and they are mainly gathered on the slopes of Mounts Merapi, Merbabu and Ungaran. ${ }^{25}$ From the technological point of view, the bathing places of Central Java are rather simple. They are built in areas where underground water is abundant and found (almost) at ground level. The water, originating from a spring or the underground part of a river, filters upwards through a floor made of river stones, and fills the pool. The pool may be single or double, in which case it is linked to a second water tank via a short pipe - there is no evidence for a connection with an irrigation system. ${ }^{26}$ The fact that the pools were fed by underground water - and not surface water - certainly helped in maintaining their water level whatever the debit of the nearby rivers.

As for their actual architecture, variances are quite numerous. Certain bathing places (Pengilon, Sidomukti, Wujil) were associated with temples built on a hilltop, while other were not (Cabean Kunti, Payak, Kuwaringan, Umbul) - but in those places, temples might have been built on flat ground, directly near the water tanks. ${ }^{27}$ The bathing places may count a single pool (Payak), a double pool (Kuwaringan, Pengilon, Sidomukti, Umbul) or several separate water basins (Cabean Kunti). The poor state of preservation of these sites does not allow a clear reconstitution of their ornamentation, but it seems that carved pieces were mostly limited to mouldings, pilasters, waterspouts and kala, with the notable exception of Cabean Kunti.

Actually, bathing places of East Java demonstrate at least the same degree of variance. ${ }^{28}$ The importance of water in their conception, a location mostly away from the main populated centres and an association with specific elements of the landscape (springs, hilltops, mountains) constitute the common denominator between the ancient bathing places of Central and East Java.

The symbolism of Eastern Javanese bathing places has been thoroughly studied by Patt, who concluded that the main themes expressed in their ornamentation and architecture was that of amrta, the elixir of immortality which was produced during the Churning of the Ocean. ${ }^{29}$ The theme was alluded to by the presence of Vaishnava sculptures, ${ }^{30}$ carvings of Rahu, ${ }^{31}$ Garuda, naga $a^{32}$ and, more generally representations of Mount Meru as the source of amrta. In Central Java, however, no element referring clearly to the Churning of the Ocean is present. Sculptures either represent water-related animals, or are of obvious Shaiva character. One thus gets the impression that the symbolism of Central Javanese bathing places was less specific and that it related more generally to water as source of fertility and life. It is here interesting to note that although the art of Central Java is often viewed as: 
more 'Indian' and that of East Java more 'Javanese or Javanized', it seems that in the case of bathing places, Indian myths were more deeply integrated in East Javanese artworks. It is nevertheless possible that the association of bathing places and temples (and especially temples on hilltops) was a reference to Mount Meru as the source of life-giving water - but the water symbolism of Vishnu is here absorbed by Shiva, whose most common representation, the lingga, is also related to life and fertility. ${ }^{33}$ In this perspective, bathing places of Central Java seem closer to Songgoriti than to Belahan and Jolotundo.

As for the function of the water tanks of Central Java, their relative rarity and the singularity of their location certainly casts doubt on their use as simple ablution tanks, where one purifies oneself before entering a temple. ${ }^{34}$ The water tanks were not part of the standard architectural programme of Javanese temples and were clearly built on specific points of the landscape, possibly because the waters of these local springs or rivers were supposed to have exceptional properties. ${ }^{35}$ F.D.K. Bosch's analysis of the guru-tridentspring motif, ${ }^{36}$ common to many Javanese myths, which has already been used by Patt in the case of Songgoriti, ${ }^{37}$ might shed an interesting light on our understanding of Central Javanese bathing places. In the myth - which is still told in modern folk stories - a guru, often with Shaiva attributes, gives evidence of his supernatural powers by planting his priestly staff into the ground and creating a spring, river or lake. It is possible that bathing places of Central Java were built on the spots where such an event had supposedly taken place, possibly superimposing the image of the sage bringing a new, powerful religion, over pre-Hindu beliefs related to the magical virtues of certain waters.

\section{References}

F.D.K. Bosch, 'Inventaris der Hindoe-oudheden op den grondslag van Dr. R.D.M. Verbeek's Oudheden van Java. Tweede deel', Rapporten van den oudheidkundigen dienst in Nederlandsch-Indië (1915), pp. 1-376.

F.D.K. Bosch, 'Guru, Trident and Spring', in: Idem, Selected Studies in Indonesian Archaeology (Koninklijk Instituut voor Taal-, Land- en Volkenkunde, translation series 5), The Hague, 1961, pp. 153-170.

J.A.B. van Buitenen (trans.), The MahÇbhÇrata, I: The Book of Beginning, Chicago, 1973.

R.H.T. Friederich, ?Over de omgeving van het Oengaran-gebergte', Tijdschrift voor Indische taal-, land-en volkenkunde 19 (1870), pp. 501-520.

R.H.T. Friederich, ?Rapport over reizen gedaan op Java', Tijdschrift voor Indische taal-, land en volkenkunde 23 (1876), pp. 42-111.

J. Knebel, 'Beschrijving der Hindoe-oudheden in de Residentie Soerakarta, behalve de reeds beschrevene in de Oudheidkundige rapporten 1909', Rapporten van de Commissie in Nederlandsch-Indië voor oudheidkundig onderzoek op Java en Madoera (1910), pp. 55-117.

N.J. Krom, 'Inventaris der Hindoe-oudheden op den grondslag van Dr R.D.M. Verbeek's Oudheden van Java. Eerste deel', Rapporten van den oudheidkundigen dienst in Nederlandsch-Indië (1914), pp. 1-358.

N.J. Krom, Inleiding tot de Hindoe-Javaansche kunst, The Hague, 1923, 3 vols.

N.J. Krom, 'Oudheden bij Bojolali in 1841', Oudheidkundig Verslag (1925), pp. 174183.

W.D. O'Flaherty, Ascetism and Eroticism in the Mythology of Shiva, London, 1973.

J.A. Patt, The Use and Symbolism of Water in Ancient Indonesian Art and Architecture (unpublished PhD thesis), Ann Arbor, 1979.nnloaded from Brill.come4/26/2023 02:29:10PM 
T.A. Resink, 'Belahan or a Myth Dispelled', Indonesia 6 (1969), pp. 1-34.

A. Roxas-Lim, 'Caves and Bathing Places in Java as Evidence of Cultural Accommodation', Asian Studies 21 (1983), pp. 107-144.

W.F. Stutterheim, 'Oudheidkundig verslag over 1937', Oudheidkundig Verslag (1937), pp.1-36.

Suaka peninggalan sejarah dan purbakala Yogyakarta (1985) 'Daftar peninggalan sejarah dan purbakala benda bergerak di propinsi Daerah Istimewa Yogyakarta, Bogem.' Unpublished transcript.

B.D. Tjahjono, 'Budaya marginal masa klasik di Jawa Tengah, Yogyakarta', Balai Arkeologi Yogyakarta (Berita penelitian arkeologi, 12), 2000.

R.D.M. Verbeek, Oudheden van Java; lijst der voornaamste overblijfselen uit den hindoetijd op Java met eene oudheidkundige kaart, The Hague/Batavia, 1891.

\section{Notes}

1. Patt 1979, pp. 14-15.

2. Dusun Cabean Kunti, desa Kunti, kecamatan Cepogo, kabupaten Boyolali, propinsi Jawa Tengah.

3. Dusun Payak, desa Srimulyo, kecamatan Piyungan, kabupaten Boyolali, propinsi Daerah Istimewa Yogyakarta.

4. Dusun Dawung, desa Bokoharjo, kecamatan Prambanan, kabupaten Sleman, propinsi Daerah Istimewa Yogyakarta.

5. Dusun Candi Umbul, desa Kertoharjo, kecamatan Grabag, kabupaten Magelang, propinsi Jawa Tengah.

6. Friederich 1876, p. 104; Verbeek 1891, p. 151; Krom 1914, p. 228.

7. Krom 1923, I, p. 409.

8. Dusun Kuwaringan, desa Bakulan, kecamatan Cepogo, kabupaten Boyolali, propinsi Jawa Tengah.

9. Knebel 1910, pp. 95-96; Bosch 1915, p. 95.

10. Krom 1923, I, p. 221.

11. Krom 1914, p. 189.

12. Friederich 1870, p. 505; 1876, p. 75.

13. Krom 1923, I, p. 224.

14. Krom 1923, I, p. 223; Krom 1914, p. 173. According to Verbeek (Verbeek 1891, p. 90), those sculptures were simply bulls, a much more probable identification.

15. Dusun Bendosari, desa Sidorejo, kecamatan Gringsing, kabupaten Batang, propinsi Jawa Tengah.

16. Dusun Klotok, desa Doplang, kecamatan Bawen, kabupaten Semarang, propinsi Jawa Tengah.

17. Dusun Ngepos, desa Donoharjo, kecamatan Ngaglik, kabupaten Sleman, propinsi Daerah Istimewa Yogyakarta.

18. Dusun Jebug, desa Tegal Waton, kecamatan Tengaran, kabupaten Semarang, propinsi Jawa Tengah.

19. Dusun Wujil, desa Wujil, kecamatan Bergas, kabupaten Semarang, propinsi Jawa Tengah.

20. For Bendosari, see Tjahjono 2000, p. 40. For Kaliklotok, see Verbeek 1891, p. 93

Krom 1914. p. 173; Krom 1923, I, p. 223. For Ngepos, see Verbeek 1891, p. 221;

Bosch 1915, p. 18; Suaka 1985, pp. 96, 98, 103. For Sanjaya, see Friederich 1876, p. 72; Verbeek 1891, pp. 96-97; Sutterheim 1937, p. 26. For Wujil, see Friederich 1870, p. 506; Idem 1876, p. 73; Verbeek 1891, p. 89; Krom 1923, I, p. 222.

21. Dusun Candi Kidul, desa Candi Gatak, kecamatan Cepogo, kabupaten Boyolali, propinsi Jawa Tengah. The site is also known as Sukoh, Lor and Bungalan.

22. Verbeek 1891, p. 194; Bosch 1915, p. 97; Krom 1925, p. 175.

23. Bosch 1918, p. 97.

24. C.J. van der Vlis, quoted in Krom 1925, pp. $175 \mathrm{ff}$.

25. With the exception of Payak, located on the plain south of Prambanan.2023 02:29:10PM 
26. The hypothesis that these bathing places might have had a purely utilitarian role is contradicted by the discovery of religious pieces at all the sites: sculptures, lingga, yoni or peripih.

27. Vestiges at Kuwaringan and Umbul suggest at least the presence of miniature temples in the direct vicinity of the pools. At Payak, the surroundings of the bathing place are covered by a layer of volcanic debris several metres deep and have not been excavated. At Cabean Kunti, however, there does not seem to have been anything else but the pools.

28. Patt 1979, p. 477.

29. Patt 1979, p. 479.

30. Vishnu is one of the main characters of this myth. It is he who helped the deva to produce the amrta by using Mount Mandara as a pivot, the naga Wasuki as a rope and thus churn the Ocean of milk. A sculpture of Vishnu allegedly comes from Belahan, as well as two spouts representing female deities and often identified as Sri and Laksmi, the consorts of this god (Krom 1923, II, p. 42; Resink 1969; Patt 1979 , p. $165 \mathrm{ff}$.

31. A Rahu water spout has been found at Belahan (Resink 1941). The identification as Rahu, an asura who tempted to steal amrta from the gods and whose head was severed by Vishnu, is questionable. It might as well be a more general representation, like the kala heads that overhang entrance doors of temples in East and Central Java.

32. Garuda is the mount of Vishnu. In India and Southeast Asia, snakes are commonly associated with water and the underworld. The occurrence of both Garuda and naga is however reminiscent of an episode of the Mahabharata in which they competed over the possession of amrta (Van Buitenen 1973, pp. 76-91; Patt 1979, pp. 234236). At Jolotundo, a naga water spout adorned the southern basin, while garuda is visible on the northern one.

33. In India, Shiva had already absorbed some of Indra's water symbolism (O'Flaherty 1973, pp. 34, 40-42, 282, 287; Patt 1983, p. 17).

34. Such tanks are common in Indian architecture, but they are generally plain (Patt 1979, p. 14).

35. At candi Umbul and Ngempon - a site near Mount Ungaran where there is no bathing place as such but a well - hot waters from the local spring is still said to have curative powers (notes from fieldwork in Central Java, July 2003). At Sanjaya, rituals involving prayer before a lingga-yoni and a purification bath were still witnessed by A. Roxas-Lim in 1980 (Roxas-Lim 1983, p. 140).

36. Bosch 1961.

37. Patt 1979, pp. 88-96. 